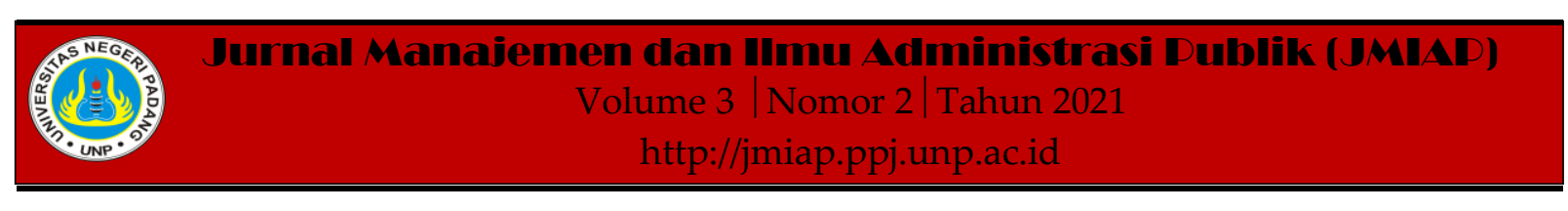

\title{
DAMPAK BUDAYA KERJA DALAM PENERAPAN APLIKASI E-PLANNING UNTUK MEWUJUDKAN GOOD GOVERNANCE
}

\author{
Tomi Satria Maggara ${ }^{1(a)}$, Aldri Frinaldi ${ }^{2(b)}$ \\ ${ }^{1}$ Jurusan Ilmu Administrasi Negara, Universitas Negeri Padang \\ ${ }^{2}$ Jurusan Ilmu Administrasi Negara, Universitas Negeri Padang \\ a)tommysatriamaggara@gmail.com, ${ }^{b)}$ alfrinaldi@gmail.com
}

\begin{abstract}
This study describes the impact of work culture in implementing the e-planning application to realize good governanc e studies in the Planning, Research and Development Agency of 50 Kota. There search method used is descriptive qualitative, because the problems are complex so that it requires interviews and observations to get valid data. The selection of informants was carried out by using purposive sampling technique. Based on the results of the research that has been done, it can be concluded that the impact of work culture in implementing E-Planning applications to achieve Good Governance at Bapelitbang Kabupaten 50 Kota it has had a good impact but there are still some problems that the authors haveen countered, among others: there are still delays in the preparation and inp $t$ of planning documents, there are no awards given to employees, accommodation of RPJPD programs in application E-Planning and there are still employees who don't understand how to use the E-Planning application.

Keywords : Work Culture, Good Governance, E-Planning, 50 Kota Regency

Corresponding author. Email.tommysatriamaggara@gmail.com

How to cite this article. Maggara, T. Satria \& Frinaldi, A. (2021). Dampak Budaya Kerja dalam Penerapan Aplikasi E-Planning untuk Mewujudkan Good Governance. Jurnal Manajemen dan Ilmu Administrasi Publik (JMIAP) Jurusan Ilmu Administrasi Negara Fakultas Ilmu Sosial Universitas Negeri Padang, Volume 3 (2), Hal. 135-143.

http://jmiap.ppj.unp.ac.id

Copyright@2021. Published by Labor Jurusan Ilmu Administrasi Negara FIS UNP, Padang
\end{abstract}


Tomi Satria Maggara, Aldri Frinaldi I Dampak Budaya Kerja dalam Penerapan Aplikasi E-Planning untuk Mewujudkan Good Governance

\section{PENDAHULUAN}

Bapelitbang merupakan badan yang mengemban tugas mengenai perencanaan, penelitian dan pengembangan, karena hal ini Bapelitbang wajib mempunyai suatu cara ataupun strategi seperti menciptakan sebuah alat yang bertujuan untuk memperlancar apa yang telah diperencanakan dan dapat berlangsung sesuai pada tujuannya, dievaluasi dan dapat dipertanggungjawabkan. Di era teknologi internet atau pun yang familiar disebut sebagai electronic government, telah diciptakan suatu system untuk membantu tujuan tersebut system tersebut adalah Aplikasi E-planning. Aplikasi E-planning adalah system penginputan, penyusunan dan pengawasan RKPD, KUA/PPAS Perubahan, RKPD Perubahan Kabupaten maupun Provinsi yang bertujuan untuk menyeselesaikan penginputan dan penyusunan dokumen perencanaan dengan cepat dan mudah.

Salah satu Kabupaten yang menerapkan aplikasi E-planning ini adalah Kabupaten Lima Puluh Kota. Sistem Informasi Perencanaan Pembangunan Daerah yang familiar disebut dengan aplikasi E-Planning memudahkan Bapelitbang Kabupaten 50 Kota untuk melakasanakan tugasnya seperti mengkoordinasikan penyusunan dokumen perencanaan, pengendalian dan pelaksanaan rencana pembangunan daerah, tentu saja dengan hal ini dbertujuan agar terciptanya perencanaan pembangunan yang baik, efektif dan efisien serta telah terintegrasi.

Aplikasi E-planning merupakan suatu system yang bertujuan untuk mewujudkan Good Governance yang lebih transparansi dalam penyelenggaraan pemerintahan Kabupaten Lima Puluh Kota sejahtera dan dinamis berlandaskan "yang mantap" iman dan taqwa.

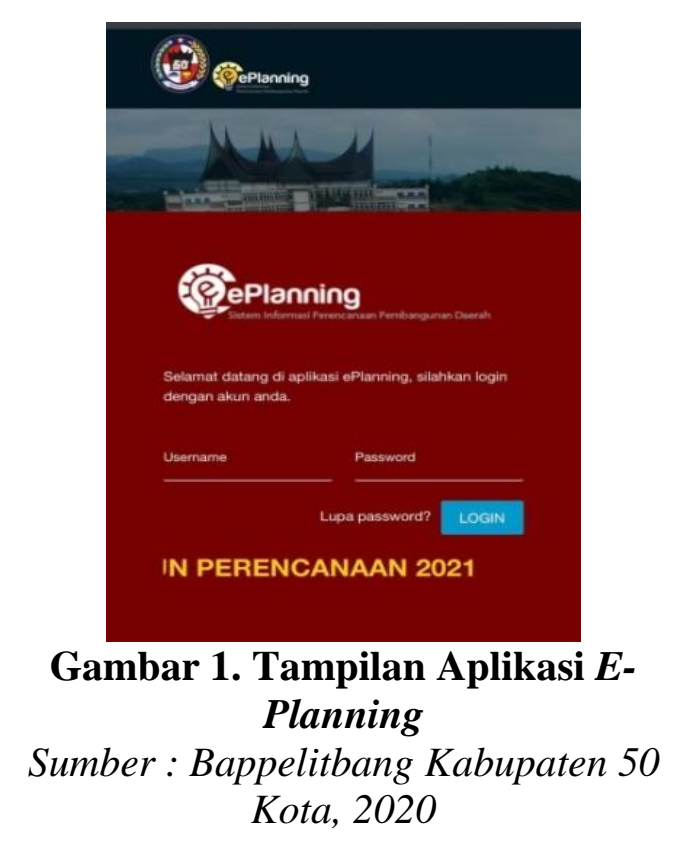

Berdasarkan hasil wawancara dan observasi dan data pendahuluan yang penulis peroleh terdapat beberapa masalah terkait Sumber Daya Manusia, seperti masih terdapat pegawai yang kesulitan dalam menyusun dokumen rencana pembangunan dalam bentuk aplikasi, dikarenakan kurangnya pemahaman dan belum mengerti pemakaian aplikasi $E$ Planning sehingga sering terjadi keterlambatan dalam penginputan data. Hal ini dikarenakan kurangnya sosialisasi dan pelatihan yang dilaksanakan untuk pelatihan E-Planning.

Permasalahan selanjutnya terkait sarana dan prasana, untuk menunjang keberhasilan penerapan aplikasi E-Planning di perlukan adanya sarana dan prasarana yang memadai. Di Bapelitbang Kabupaten 50 Kota tidak semua pegawai disediakan Komputer/laptop, kualitas jaringan yang kurang baik juga menjadi penyebab masalah dalam penerapan aplikasi $E$ Planning ini.

Permasalahan lain nya yaitu Aplikasi EPlanning yang telah diterapkan di Bapelitbang Kabupaten Lima Puluh Kota belum terstandarisasi dan belum sepenuhnya sesuai dengan tahapan dan mekanisme dalam Permendagri Nomor 86 Tahun 2017.

Permasalahan terkait budaya kerja yang penulis temukan adalah kurangnya 
tanggung jawab pegawai dalam melaksanakan tugasnya, seperti adanya pegawai yang terlambat dan tidak disiplin dalam mengerjakan tugasnya sehingga menyebabkan tidak efisiennya penerapan E-planning di Bapelitbang Kabupaten 50 Kota.

Pada penerapan aplikasi E-Planing terdapat juga masalah keadaptasian, seperti masih ada program yang belum terakomodasi pada aplikasi E-Planning yaitu seperti RPJPD . Hal ini tentu tidak berdampak baik terhadap kualitas suatu perencanaan yang akan dihasilkan Bapelitbang Kabupaten 50 kota. Dari sudut kepuasaan pada aplikasi E-Planning masi ada dari pegawai Bapelitbang yang mengeluh terutama pada program baru, penomoran rekening pada program baru membutuhkan proses yang lama sehingga memakan waktu yang lama pada pemrosesannya.

Berdasarkan latar belakang di atas, maka penulis tertarik melakukan penelitian dengan judul "Dampak Budaya Kerja dalam Penerapan Aplikasi E-planning untuk mewujudkan Good Governance (Studi Kasus di Badan Perencanaan, Penelitian dan Pengembangan Kabupaten Lima Puluh Kota)". Rumusan masalah yang dikemukakan dalam penelitian ini ada sebagai berikut:

1. Bagaimana dampak budaya kerja dalam penerapan aplikasi E-planning di Bapelitbang Kabupaten 50 Kota?

2. Bagaimana dampak penerapan aplikasi E-Planning di Bapelitbang mewujudkan Good Governance?

\section{TINJAUAN PUSTAKA}

\section{Konsep Budaya Kerja}

Menurut Hadari Nawawi dalam (Supratman, 2018) budaya kerja merupakan suatu yang dapat dilihat dari ceriminan kebiasaan yang diperbuat berkali-kali antar sesasama pegawai, di dalam suatu instansi maupun organisasi penyimpangan maupun perlenggaran pada kebiasaan tersebut biasanya tidak diberi sanksi yang tegas, tetapi dari pelaku organisasi maupun suatu instansi telah menyepakati secara moral bahwa kebiasaan yang berulang kali ini adalah kebiasaan yang harus dipatuhi dalam pelaksanaan tugas maupun pekerjaan untuk mencapai suatu tujuan yang telah ditentukan.

Adapun (Frinaldi, 2014) berpendapat bahwa budaya kerja merupakan suatu acuan yang menjadi dasar baik secara terlihat ataupun tidak terlihat dalam diri seorang pegawai yang dilihat dari perspektif nilai, pemahaman dan kemampuan bagaimana cara bekerja, norma, serta pola pikir, dan sikap setiap pegawai dalam menjalankan suatu pekerjaan.

Begitu juga menurut (Kasandra, Frinaldi, \& Lanin, 2018) Budaya kerja pada suatu organisasi yang didasarkan dengan pedoman pada kualitas hidup sebagai nilai ke dalam perilaku ataupun sifat yang menjadi pendorong bagi segelintir masyarakat maupun pada suatu organisasi.

(Frinaldi, 2017) mengatakan terdapat enam indikator untuk melihat dan mengukur budaya kerja pada organisasi maupun instansi, yaitu : (1)Kepemimpinan, (2)Penampilan, (3)Kesadaran akan waktu (4)Komunikasi (5)Penghargaan dan pengakuan (6)Nilai dan kepercayaan

Maka dapat dilihat budaya kerja memiliki peran yang berguna terhadap organisasi. Penerapan budaya kerja tentu juga akan berpengaruh pada kegiatan maupun aktifitas serta keberlangsungan sesebuah organisasi yang berdampak baik sehingga menimbulkan sebuah citra yang baik di sebuah organisasi. (Frinaldi \& Embi, 2011).

\section{Konsep E-Government}

Menurut Wibisono dan Sulistyaningsih dalam (Ariyanto, 2015) Electronic Government bisa dipergunakan dan dimanfaatkan pemerintah sebagai teknologi informasi dan komunikasi pada proses penghantar jasa ataupun administrasi. Electronic Government menyatukan informasi dan komunikasi, pada jaringan, internet dan komputerisasi melalui pemerintah yang bertujuan untuk 
meningkatkan kualitas pelayanan kepada masyarakat.

\section{Konsep Good Governance}

Menurut Hardiwinoto dalam (Astriandy, 2018) Good governance merupakan suatu peyelenggaraan, pengelolaan ataupun sebagai manajemen pada pembangunan yang bertanggungjawab dan sejalan dengan prinsip demokrasi tujuannya yaitu agar terhindar dari adanya suatu kesalahan pada alokasi dana maupun investasi, selain itu juga untuk pencegahan agar tidak terjadinya korupsi baik secara politik ataupun secara administratif. Dengan adanya Good governance akan berdampak baik karena Good governance menjalankan disiplin anggaran serta political framework untuk tumbuhnya aktifitas usaha.

Menurut UNDP dalam (Sedermayenti, Good Governance "Kepemerintahan Yang Baik" Bagian Kedua Revisi, 2012) terdapat enam prinsip-prinsip untuk mewujudkan Good Governance yaitu:

1) Partisipasi (partisipation), setiap orang, mempunyai hak yang sama ketika proses pengambilan suatu kebijakan, baik secara langsung, ataupun melalui instansi perwakilan, tentunya harus sejalan dengan kepentingan dan pandangan masing-masing;

2) Kepastian Hukum (rule of law), Konsep atau dasar pada aturan hukum dan perundang-undangan harus berlandaskan keadilan, dipraktekan, ditegakkan dan dipatuhi secara utuh;

3) Transparansi (transparancy), transparansi sangat perlu dan harus dibangun dalam rangka kebebasan dalam mendapat aliran informasi;

4) Responsif (responsiveness), institusi dan metodenya wajib dan harus digerakkan untuk melayani berbagai pihak yang berkepentingan (stakeholders);

5) Orentasi Konsensus (concensus orientation), pemerintahan yang baik bisa menjadi penengah bagi berbagai kepentingan yang berbeda-beda tujuannya yaiu agar tercapainya kesepakatan ataupun konsesus yang baik untuk kepentingan masing-masing pihak, dan jika dimungkinkan juga dapat masing-masing pihak;

6) Kesetaraan (equity), pemerintahan yang baik akan berupaya memberi kesempatan yang baik bagi setiap orang untuk meningkatkan kesejahteraan dan kualitas hidupnya;

7) Efisien dan Efektif (efficiency and effectiveness), setiap metode kegiatan dan institusi bertujuan agar meghasilkan sesuatu yang benar-benar sesuai dengan urgensi melalui pemanfaatan yang sebaik-baiknya dari sumber-sumber yang tersedia;

8) Akuntabilitas (accountability), para pengambil kebijakan dalam organisasi sector publik, swasta, dan masyarakat memiliki pertanggungjawaban kepada publik, sebagaimana halnya kepada para penguasa (stakeholders);

9) Visi Strategis (strategic vision), para pemimpin dan masyarakat memiliki pemikiran yang luas secara jangka panjang tentang keberlangsungan pemerintahan yang baik dan pembangunan manusia, bersamaan dengan dirasakan kebutuhan pada pembangunan itu.

\section{METODE PENELITIAN}

Metode penelitian pada penelitian ini menggunakan metode kualitatif deskriptif. Lokasi penelitian pada penelitian ini yaitu di daerah Kabupaten Lima Puluh Kota. Untuk pemilihan informan menggunakan teknik purposive sampling. Data dikumpulkan melalui observasi, wawancara, dan dokumentasi. Teknik triangulasi digunakan untuk menguji keabsahan data yang menggunakan pihak luar untuk dijadikan pembanding sehingga bisa ditarik suatu kesimpulan.

Terkait penelitian ini, informan haruslah didasarkan pada relevansi pengetahuan mengenai budaya kerja pegawai dalam penerapan aplikasi E-Planning di Bapelitbang Kabupaten 50 Kota. Informan yang berkemungkinan berhubungan langsung degan penelitian penulis yaitu: 
Tomi Satria Maggara, Aldri Frinaldi I Dampak Budaya Kerja dalam Penerapan Aplikasi E-Planning untuk Mewujudkan Good Governance

Tabel 1. Informan Penelitian

\begin{tabular}{|l|l|l|}
\hline No & \multicolumn{1}{|c|}{ Nama } & \multicolumn{1}{c|}{ Status } \\
\hline 1. & $\begin{array}{l}\text { Widya Putra S.Sos, } \\
\text { M.Si }\end{array}$ & $\begin{array}{l}\text { PLT Kepala } \\
\text { Badan }\end{array}$ \\
\hline 2. & $\begin{array}{l}\text { Sofyan Hendri } \\
\text { S.Si, M.S.E }\end{array}$ & $\begin{array}{l}\text { Kepala } \\
\text { Bidang PDPE }\end{array}$ \\
\hline 3. & $\begin{array}{l}\text { M. Ranggi Taruna } \\
\text { S.STP }\end{array}$ & $\begin{array}{l}\text { Kasubid } \\
\text { Perencanaan } \\
\text { dan } \\
\text { Pendanaan }\end{array}$ \\
\hline 4. & $\begin{array}{l}\text { Yelsa Devina } \\
\text { Yuanita ST }\end{array}$ & $\begin{array}{l}\text { Kasubid } \\
\text { Pengendalian, } \\
\text { Evaluasi dan } \\
\text { Pelaporan }\end{array}$ \\
\hline 5. & Meironi ST & $\begin{array}{l}\text { Kasubid Data } \\
\text { dan Informasi }\end{array}$ \\
\hline
\end{tabular}

Informan dalam penelitian ini adalah 5 orang pegawai Badan Perencanaan Penelitian dan Pengembangan Kabupaten 50 Kota.

\section{HASIL DAN PEMBAHASAN}

Dampak budaya kerja dalam penerapan aplikasi E-Planning di Bapelitbang Kabupaten 50 Kota

Untuk melihat dampak budaya kerja dalam penerapan aplikasi E-Planning di Bapelitbang Kabupaten 50 Kota maka dilihat dengan menggunakan teori budaya kerja. Menurut (Frinaldi, 2017) setidaknya terdapat beberapa unsur yang harus terpenuhi dalam budaya kerja diantaranya sebagai berikut:

\section{1) Kepemimpinan}

Berdarsarkan temuan peneliti kepemimpinan dalam penerapan aplikasi EPlanning dapat dikatakan sudah berdampak baik karena pemimpin membagi pegawai kedalam kelompok kerja seusai dengan sk yang telah dikeluarkan oleh kepala daerah dan sebelum di operasikan nya sistem atau aplikasi E-planning pimpinan juga telah berupaya melakukan pertemuan untuk pembekalan berupa pelatihan terhadap pegawai yang akan menjalankan aplikasi EPlanning, selain itu pimpinan juga menjalin hubungan dengan saling berkoordinasi dengan melakukan rapat bulanan guna untuk mengevaluasi penyempurnaan penerapan aplikasi E-Planning.

\section{2) Penampilan}

Berdasarkan temuan peneliti tampilan pada aplikasi E-Planning tidak jauh berbeda dengan tampilan aplikasi $E$ Planning milik daerah lain karena aplikasi E-Planning sendiri merupakan sistem perencanaan yang telah diatur dalam permendagri no 86 tahun 2017 namun demikian Bapelitbang Kabupaten 50 kota telah berupaya membuat tampilan pada aplikasi E-Planning dengan jelas dan mudah di mengerti sehingga pada saat menggunakan aplikasi E-Planning pegawai bisa dengan sangat cepat untuk memahaminya.

\section{3) Kesadaran Akan Waktu}

Berdsarkan temuan peneliti pada penerepan aplikasi E-Planning, Bapelitbang Kabupaten 50 Kota telah berupaya dengan memfasilitasi system berbatas waktu pada aplikasi E-Planning, hal ini tentu sangat berdampak baik pada penerapan aplikasi E-Planning selain itu dengan dilengkapi dengan system berbatas waktu tersebut tentu akan menjadi salah satu factor pendorong bagi pegawai untuk bekerja lebih disiplin terhadap waktu, tujuannya yaitu agar tidak terjadinya keterlambatan dalam penginputan dokumen perencanaan. Namun masih sangat disayangkan masih ada ditemui keterlambatan dalam penginputan dokumen perencanaan tersebut, yang mengakibatkan dokumen tersebut tidak bisa diterima oleh system pada Aplikasi E-Planning.

\section{4) Komunikasi}

Berdasarkan temuan peniliti komunikasi yang terjalin antara sesama pegawai dalam penerepan aplikasi $E$ Planning ini dapat dikatakan sudah berdampak baik karena pegawai memiliki hubungan yang baik antar sesama pegawai, sehingga dalam berkoordinasi bisa melalui cara non formal yaitu menggunakan grup whatshapp, selain itu pegawai juga 
berkoordinasi melalui rapat secara berkala, ketika ada arahan dari pimpinan untuk melakukan rapat, rapat ini tentunya bertujuan untuk membahas tentang kegiatan pada penerapan aplikasi E-Planning.

\section{5) Penghargaan dan Pengakuan}

Berdasarkan temuan peneliti dalam penerapan aplikasi E-Planning ini sangat di sayangkan tidak adanya pemberian penghargaan bagi pegawai hal ini menyebabkan kurangnya motivasi dan semangat pegawai dalam bekerja. Sehingga pegawai hanya menganggap pekerjaannya adalah tuntutan yang harus dan wajib dilaksanakan dengan perasaan terpaksa.

\section{6) Nilai dan Kepercayaan}

Berdasarkan temuan peneliti nilai dan kepercayaan yang dianut Bapelitbang kabupaten 50 Kota dalam penerapan aplikasi E-planning ini sudah berdampak baik. Hal ini dapat dilihat dalam menjalankan tugas, pegawai telah berpedoman pada tupoksi yang telah dikeluarkan oleh Kepala Daerah selain itu dalam menggunaka aplikasi E-Planning Bapelitbang Kabupaten 50 Kota berpedoman dan mengacu pada Permendagri No. 86 Tahun 2017 dengan adanya tupoksi dan Permendagri No. 86 Tahun 2018 tentu akan meminimalisisir pegawai untuk melakukan kesalahan.

\section{Dampak penerapan aplikasi $E$-Planning untuk mewujudkan Good Governance}

Adapun untuk melihat penerapan pada aplikasi E-planning di Bapelitbang Kabupten 50 Kota ini sudah bertujuan untuk mewujudkan Good Governance yaitu dapat dilihat dengan menggunakan unsur-unsur Good Governance seperti yang dikemukakan oleh UNDP dalam (Sedermayenti, 2012) yaitu:

\section{1) Participation (Partisipasi)}

Berdasarkan temuan peneliti dapat dikatakan bahwa penerapan pada aplikasi E-Planning sudah semua pegawai yang berpartisipasi baik dalam menjalan tugas maupun dalam menyamapaikan pendapat, hal ini dapat dilihat dengan adanya SK tim yang dikeluarkan oleh kepala daerah kepada pegawai maupun operator terkait, sehingga dalam menjalan tugas pegawai berperan sesuai tugas yang telah ditentukan. Tidak hanya itu saja pegawai juga melakukan rapat tatap muka secara berkala yang dimana pada rapat ini pegawai bisa menyampaikan aspirasi-aspirasi mereka terkait perkembangan dan pembaharuan pada aplikasi E-Planning hal ini tentu sangat berdampak paik dalam penerepan aplikasi E-Planning di Kabupaten 50 Kota.

\section{2) Rule Of Law (Penegakan Aturan Hukum)}

Berdasarkan temuan peneliti, dalam penerapan aplikasi E-Planning Bapelitbang Kabupaten 50 Kota sudah berkomitmen dengan aturan yang berlaku, yaitu telah mengacu pada Permendagri No.86 Tahun 2017 selain itu yang penulis temui dalam penerapan aplikasi E-Planning pegawai di Bapelitbang dalam menjalan tugasnya juga telah berpedoman pada SOP yang berlaku, hal ini tentu sangat berdampak baik pada penerapan aplikasi E-Planning di Bapelitbang Kabupaten 50 Kota.

\section{3) Transparancy (Tranparansi)}

Berdasarkan temuan peneliti meskipun aplikasi E-Planning di Bapelitbang tidak diperuntukan untuk public, tetapi untuk mewujudkan suatu transparansi dalam penerepan aplikasi E-Planning, Bapelitbang Kabupaten 50 Kota telah berupaya dengan memfasilitasi aplikasi $E$ Planning dengan sistem keamanan yang memiliiki jejak digitalnya sehingga mudah untuk diawasi, selain itu tentunya dengan terdapatnya jejak digital tersebut sangat dapat meminimalisirkan untuk terjadinya kegiatan-kegiatan menyimpang.

\section{4) Responsivenes (Responsif)}

Berdasarkan temuan peneliti jauh sebelum akan diterapkan aplikasi $E$ planning, Bapelitbang Kabupaten 50 Kota telah berupaya dengan memberikan pembekalan kepada pegawai, hal ini dapat dilihat dengan diadakan nya sosialisasi dan 
pelatihan oleh Bapelitbang Kabupaten 50 Kota, sehingga pada saat aplikasi $E$ planning ini telah diterapkan pegawai sudah siap dan mengerti dalam mennggunakannya nya.

Meskipun begitu masih terdapat pegawai yang belum langsung mengerti dalam menggunakan aplikasi E-Planning namun, Bapelitbang Kabupaten 50 Kota akan terus berupaya memberi pembekelan berupa pelatihan maupun sosialisasi, dengan begitu tentu hal ini sangat berdampak baik dalam penerapan aplikasi E-Planning.

\section{5) Consesus Orientation (Berorientasi Pada Konsesus)}

Berdasarkan hasil temuan peneliti pada penerapan aplikasi E-Planning ini masih bertumpu pada kesepakatan yang didapati dari hasil musyawarah hal ini dapat dilihat dari diadakan nya rapat tatap muka yang berkaitan tentang perkembangan dan pembaharuan aplikasi E-Planning, tidak hanya itu saja rapat tatap muka juga diadakan dalam penginputan dokumen perencanaan. Sehingga sudah dapat dipastikan bahwa dalam penerapan aplikasi E-Planning ini masih mengacu pada kesepakatan bersama agar penerapan pada aplikasi E-Planning sesuai dengan tujuan yang telah ditentukan.

\section{6) Equity (Kesejahteraan)}

Berdasarkan hasil temuan peneliti Bapelitbang Kabupaten 50 Kot telah berupaya menciptakan aplikasi E-Planning untuk memudahkan pegawai dalam menjalankan tugasnya. Tentu saja dengan diterapkannya aplikasi E-Planning sangat berdampak baik karena memudahkan pegawai dalam menjalankan tugasnya terutama pada penyusunan dan penginputan dokumen perencanaan Karena dengan adanya aplikasi E-Planning ini pegawai hanya menjalankan tugas melalui system, yang pasti nya akan menghemat waktu pegawai dalam menjalankan tugas, sehingga menciptakan kenyamanan bagi pegawai dalam bekerja.
Maka dapat disimpulkan bahwa dalam penerapan aplikasi E-Planning sangat memudahkan pegawai dalam mengerjakan tugas dan menciptakan kenyamanan bagi pegawai, dengan adanya kenyamanan dapat dipastikan bahwa akan meningkatkan kesejahteraan pegawai dalam bekerja.

\section{7) Efficiency and effectiveness (Efisien dan Efektif)}

Berdasarkan hasil yang peniliti temui dapat dikatakan bahwa dalam penerapan aplikasi E-planning ini sudah efektif,dan efisien dan dapat dikatakan sudah tepat sasaran karena tujuan diciptakan nya aplikasi E-Planning ini adalah membantu pegawai dalam mengerjakan tugasnya meskipun masih terdapat beberapa kekurangan seperti tidak terakomodasi nya program RPJPD tetapi Bapelitbang akan terus melakukan penyempurnaan pada aplikasi E-Planning ini .

\section{8) Accountability (Akuntabilitas)}

Berdasarkan hasil temuan peniliti dalam penerapan aplikasi E-Planning ini pegawai sudah sepenuhnya bertanggungjawab dalam menjalankan tugas nya dan bekerja sesuai dengan tupoksi yang ada, karena setiap pekerjaan yang dilaksanakan oleh pegawai akan diperiksa dan diminta laporan kerjanya oleh KPK, tidak hanya itu saja KPK juga akan menilai hasil kerja pegawai tersebut.

Selain itu bagi pegawai yang menggunakan aplikasi E-Planning juga telah membuat surat pernyataan agar menjalankan tugas sesuai dengan aturan yang berlaku. Hal ini tentu nya pasti akan sangat medorong pegawai untuk lebih bertanggungjawab dalam menjalankan tugasnya.

\section{9) Strategic vision (Visi strategis)}

Berdasarkan hasil temuan peneliti dalam penerapan Aplikasi E-planning pegawai Bapelitbang Kabupaten 50 Kota telah memiliki perspektif jangka panjang hal ini dapat dilihat dengan terjalin nya kerja sama dengan pihak ketiga yang bertujuan untuk melakukan perkembangan- 
perkembangan dan penyempurnaan pada aplikasi E-Planning ini, perkembangan dan penyempurnaan ini akan terus dilakukan sesuai dengan kebutuhan-kebutuhan pegawai dalam menjalankan tugasnya.

\section{PENUTUP}

Berdasarkan hasil temuan dan pembahasan yang telah dijelaskan, maka dapat penulis simpulkan:

1) Dampak budaya Kerja dalam penerapan aplikasi E-Planning di Bapelitbang Kabupaten 50 Kota, dapat dikatakan sudah berdampak baik walau masih terdapat beberapa unsur-unsur yang belum sepenuhnya terpenuhi seperti:

a. Kesadaran akan waktu, masih ada terjadinya keterlambatan pada penginputan dokumen perencanaan oleh pegawai di Bapelitbang Kabaputen 50 Kota

b. Penghargaan dan pengakuan, tidak terdapatnya penghargaan yang diberikan kepada pegawai baik dalam melakukan tugas secara umum maupun terkait penerapan pada aplikasi $E$ Planning.

2) Dampak penerapan aplikasi E-Planning untuk mewujudkan Good Governance di Bapelitbang Kabupaten 50 Kota sudah berdampak baik walau masih terdapat beberapa masalah pada unsurunsur Good Governance seperti:

a. Efektif dan efisiensi, pada aplikasi E-Planning masih belum terakomodasi program RPJPD.

b. Responsivines, masih terdapatnya pegawai yang kurang mengerti dalam menggunakan aplikasi $E$ Planning karena belum optimalnya pelatihan yang dilakukan.

Melihat kondisi dilapangan yang masih adanya terdapat beberapa masalah pada dampak budaya kerja dalam penerapan aplikasi E-Planning untuk mewujudkan Good Governance di Bapelitbang
Kabupaten 50 Kota maka penulis menyarankan:

a. Dengan telah terdapatnya sistem batasan waktu pada aplikasi $E$ Planning maka diharapkan kepada pegawai di Bapelitbang Kabupaten 50 Kota untuk tidak terlambat lagi melakukan penginputan dokumen perencanaan.

b. Diharapkan untuk memberi penghargaan bagi pegawai yang berprestasi dalam menjalankan tugasnya agar menjadi suatu pendorong bagi untuk pegawai bekerja sebaik mungkin.

c. Perlu adanya pembaharuan pada aplikasi E-Planning agar terakomodasinya program RPJPD

d. Diharapkan Bapelitbang Kabupaten 50 Kota lebih mengoptimalkan pelatihan kepada pegawai agar pegawai lebih cepat bisa untuk memahami cara menggunakan aplikasi E-planning.

\section{DAFTAR KEPUSTAKAAN}

Ariyanto, M. (2015). Analisis Pelaksanaan E-Goverment di Kantor Pelayanan Publik Pajak Pratama Serang. Universitas Sultan Ageng Tirtayasa, Fakultas Ilmu Sosial dan Politik. Serang: Tidak Dipubliasikan.

Astriandy, C. (2018). Analisis Penerapan Prinsip Good Goverment Governance Daam Pengelolaan Keuangan Desa. Universitas Sanata Dharma, Fakultas Ekonomi. Yogyakarta: Tidak Dipublikasikan.

Frinaldi, A. (2014). Pengaruh Budaya Kerja Pegawai Negeri Sipil Terhadap Pelayanan Publik di Dinas Catatan Sipil dan Kependudukan Kota Payakumbuh. HUMANUS. 
Frinaldi, A. (2017). Mengelola Budaya Organisasi dan Budaya Kerja .Acuan Bagi Akademis, Praktisi, dan Pemerhati Budaya Kerja. UNP Press.

Frinaldi, A., \& Embi, M. A. (2011). Pengaruh Budaya Kerja Etnik Terhadap Budaya Kerja Keadilan dan Keterbukaan PNS Dalam Membangun Masyarakat Madani dan Demokrasi. Humanus, $X(1)$.

Kasandra, d., Frinaldi, A., \& Lanin, D. (2018). Pengaruh Budaya kerja Pengemudi Angkutan Umum Kota Terhadap Kepuasan Penumpang di Kota Padang. Spirit, 13 April(1).

Sedermayenti. (2012). Good Governance "Kepemerintahan yang baik" Bagian kedua revisi. Bandung: CV. Mandar maju.

Sedermayenti. (2012). Good Governance "Kepemerintahan Yang Baik" Bagian Kedua Revisi. Bandung: CV.Mandar Maju.

Supratman, D. (2018). Budaya Kerja Aparatur Sipil Negara Dalam Rangka Good Governance Menuju Birokasi Berkelas Dunia. Administrasi Publik. 